\title{
STRATEGI PENGGUNAAN MEDIA DIGITAL DALAM PROMOSI KERAJINAN PARANG SUMBAWA (STUDI KASUS KOMUNITAS PANDAI BESI DESA LESENG, KECAMATAN MOYO HULU)
}

\author{
$1^{1^{*}}$ Fahrunnisa, ${ }^{2}$ Izzatul Qonitat
}

1, 2*Fakultas IImu Komunikasi Universitas Teknologi Sumbawa

*Corresponding author email: 1fahrunnisa@uts.ac.id, 2izzatqonit@gmail.com

\begin{tabular}{ll}
\hline & Abstrak \\
\cline { 2 - 3 } $\begin{array}{l}\text { Diterima : } \\
\text { Bulan September }\end{array}$ & Di era digital, penting bagi unit usaha untuk mengandalkan jaringan internet agar dapat \\
2020 & hertahan dan berkembang ke pasar yang lebih luas. Dalam penggunaanya, media digital \\
& Desa Leseng merupakan pusat perajin parang di Sumbawa yang juga memanfaatkan \\
& media digital untuk pemasarannnya. Media yang mereka gunakan adalah Facebook dan \\
& WhatsApp, tetapi dalam pemasaran belum maksimal secara pemasaran digital. Hal ini \\
& dibuktikan oleh tidak adanya akun/blog komunitas resmi dari perajin parang, tetapi \\
Diterbitkan: & hanya menggunakan akun pribadi. Maka berlandasan dari permasalahan tersebut, \\
Bulan Oktober & penelitian dilakukan bertujuan untuk mengkaji sejauh mana perajin dalam \\
2020 & memaksimalkan penggunaan media digital dalam menunjang promosi parang \\
& Sumbawa. \\
Keyword: & Penelitian menggunakan metode kualitatif dengan pendekatan studi kasus. Penelitian \\
Komunitas & dilakukan di Desa Leseng, Kecamatan MoyoHulu dengan jangka waktu penelitian dari \\
Perajin Parang,, & September-Maret 2020. Informan dari penelitian merupakan perajin parang yang \\
Perajin & menggunakan media digital dalam pemasaran produknya. Analisis pembahasan \\
Sumbawa, & menggunakan teori dari Tom Duchan dalam komunikasi pemasaran. \\
Strategi & Hasil penelitian di Desa Leseng terdapat 31 kelompok perajin parang, dan yang \\
Komunikasi, & menggunakan media digital hanya 3 kelompok perajin parang. Strategi penggunaan \\
Pemasaran & media oleh perajin parang apabila dianalisis menggunakan teori belum menerapkan \\
Media. & konsep tersebut. Dalam teori ada 4tahapan, pertama target media, perajin parang tidak \\
& menetukan target konsumen secara spesifik. Kedua tujuan media, perancangan media \\
& menggunakan media facebook dan whatsapp tetapi menggunakan akun pribadi masing- \\
& masing. Ketiga strategi, strategi yang mereka lakukan hanya menyebarkan pesan ke \\
& grup/halaman yang ada di facebook. Keempat penjadwalan media, perajin parang tidak \\
& memiliki waktu terbaik untuk melakukan promosi.
\end{tabular}

\section{PENDAHULUAN}

Ekonomi Indonesia mengalami perkembangan yang sangat pesat salah satunya, diakibatkan oleh adanya perkembangan teknologi informasi. Keberadaan teknologi informasi membuat peluang dan pengembangan ekonomi nasional menjadi lebih cepat dan efesien.
Kemajuan teknologi juga mengubah wajah perekonomian dapat dilihat dari perkembangan Revolusi 4.0, khususnya di sektor industri dan perdagangan. Revolusi ditandai dari perubahan ekonomi agraris ke ekonomi industri, penggunaan tenaga otot berubah menjadi tenaga mesin, tenaga mesin berkembang melalui tenaga listrik, lalu lahirlah komputerisasi dan global 
network atau yang biasa kita kenal adalah internet (Hoedi \& Wahyudi, 2018). Revolusi Industri 4.0 melalui konektivitas dan digitalisasinya mampu meningkatkan efisiensi rantai manufaktur dan kualitas produk, sehingga memiliki nilai jual yang lebih tinggi. Senada dengan itu, Devi \& Ferensia (2018) menjelaskan bahwa potensi-potensi yang dimiliki setiap bidang industri perlu dikolaborasikan dengan kemampuan dan pengetahuan teknologi yang terbaru, untuk menciptakan sistem ekonomi yang berjangka panjang.

Kehadiran teknologi komunikasi dan informasi menawarkan kemudahan bagi pelaku usaha terutama dalam mengembangkan peluang bisnis. Menurut Lasmadiarta (2010) dalam Zainal \& Ali (2011), pengguna internet berbanding lurus dengan pemanfaatannya dalam dunia Marketing, sehingga popoler di sebut Marketing online. Itulah alasan kenapa pemasaran produk UMKM membutuhkan peran dari media digital. Sehingga informasi dapat menyentuh semua kalangan di seluruh penjuru negeri, tanpa membutuhkan banyak biaya yang dikeluarkan sebagai operasional. Saat ini pengguna internet di Indonesia berjumlah sekitar 72,7 juta, dari jumlah tersebut $95 \%$ diantaranya adalah pengguna media sosial yakni sekitar 72 juta. Sementara 62 juta pengguna media sosial melakukan aktivitasnya dengan menggunakan mobile phone. Informasi menjadi wujud yang penting dari media sosial, karena mengkreasikan representasi identitasnya, memproduksi konten, dan melakukan interaksi berdasarkan informasi (Nasrullah, 2015:19 dalam Gumilar, 2015).
Salah satu UMKM yang berkembang di Sumbawa adalah industri Pandai besi. Pandai Besi merupakan wujud nyata dari Industri Kriya di Sumbawa. Industri pandai besi dalam hal ini menghasilkan kerajinan yang populer yaitu Parang Sumbawa. Parang Sumbawa diproduksi sejak masa kolonialisme yang berpusat di Dusun Talwa, Desa Leseng. Parang Sumbawa telah merepresentasikan nilai budaya yang melekat dan menjadi pengetahuan lokal bagi masyarakat setempat. Pandai besi Desa Leseng menjadi warisan turun menurun oleh masyarakat setempat dan dijadikan mata pencaharian

Desa Leseng menjadi salah satu pusat perajin Parang yang terkenal di Sumbawa. Selain kualitas, pembuatannya mempertahankan tenaga manusia atau menggunakan cara manual, sehingga kualitasnya tetap terjaga. Meski demikian perajin parang di desa Leseng, masih terkendala dengan pemasarannya. Pemasaran mayoritas dilakukan secara konvensional yaitu dengan dijual dipasarpasar yang ada di Sumbawa dan mendatangkan langsung pembeli ke tempat produksi. Disisi lain, beberapa kelompok sudah mulai menggunakan teknologi informasi yang dipelopori oleh pemuda setempat yang juga bekerja sebagai perajin parang. Teknologi informasi yang digunakan seperti Facebook dan WhatsApp.

Meskipun menggunakan media digital seperti Facebook dan WhatsApp, tetapi dalam penerapan pemasarannya yang masih dilakukan perindividu, ada sebagian juga yang pemasaran menggunakan digital dilakukan oleh sanak keluarga yang lain, melalu akun pribadi. Tidak ada lembaga khusus atau akun resmi untuk 
mempromosi kerajinan parang Sumbawa lebih terstruktur dan tersistematis untuk menaungi keseluruhan kelompok parang Sumbawa yang ada di Desa leseng. Berlandasan dari permasalahan tersebut, Peneliti mengkaji beberapa kelompok pandai besi yang menggunakan media digital, agar dapat melihat sejauh mana perajin dalam memaksimalkan penggunaan media dalam menunjang promosi parang, yang merupakan salah satu ikon budaya yang dimiliki Sumbawa untuk dapat dikenal oleh daerah-daerah lain. Maka, penelitian dilakukan guna mengetahui strategi penggunaan media digital dalam menunjang promosi parang Desa Leseng, Kecamatan MoyoHulu.

\section{METODE PENELITIAN}

Penelitian ini menggunakan penelitian kualitatif, Dan peneliti menggunakan pendekatan studi kasus. Fokus penelitian lebih memfokuskan pada cara perajin parang yang menggunakan media digital, bagaimana strategi komunikasi media digital sebagai sarana pemasaran dalam menunjang promosi parang kearah pasar yang lebih luas.

Subjek dalam penelitian adalah salah satu Usaha Mikro, Kecil dan Menengah (UMKM) di Kabupaten Sumbawa, yaitu Industri Pandai besi yang berada di Desa Leseng, Kecamatan Moyo Hulu. Waktu pengambilan data dilakukan 6 bulan, yaitu pada bulan September-Maret 2020. Pelaksanaan dilakukan adalah pra riset, pengumpulan data, dan analisis data.

Peneliti memfokuskan penelitian dalam mencari sumber data kepada infoman yaitu individu atau kelompok perajin parang Desa Leseng yang mengunakan media digital sebagai sarana pemasaran parang Sumbawa. Dari 31 kelompok, setelah melalui proses teknik sampling snowball, terdapat 3 kelompok yang menggunakan media digital, masing-masing diwakili oleh satu orang yang mengoperasikan media digital. hal ini untuk melihat bagaimana penggunaan media digital yang dilakukan oleh perajin parang. Adapun 3 kelompok tersebut diketuai oleh M. Saleh yang diwakilkan anggotanya Eddy untuk dusun Talwa A. Ketua Hasanuddin Muluk yang diwakilkan oleh Erwin Syahputra untuk dusun Talwa B. Ketua Ahmad yang diwakilkan oleh Pendi untuk dusun Batu Alang.

Prosedur pengumpulan data dalam penelitian kualitatif ini melibatkan tiga jenis strategi. Yaitu Observasi, Wawancara dan Dokumentasi. Setelah data diperoleh maka akan dianalisis, Analisis data dimaksudkan untuk memaknai data yang berupa teks atau gambar. Hal ini melibatkan segmentasi dan memilah-milah data. peneliti mendeksripsikan kembali dalam narasi/laporan kualitatif, sesuai dengan teori atau pisau bedah yang digunakan. Terakhir peneliti mengungkapkan kesimpulan dari penelitian ini.

\section{PEMBAHASAN}

Kelompok perajin parang, memiliki anggota kelompok yang tidak tetap, tetapi ketua kelompoknya tetap. Umumnya bengkel atau tempat produksinya berada di rumah ketua kelompok. Dalam penjualannya mereka mengutamakan penjualan secara langsung dan ada tiga cara yaitu jual pesanan (hanya dibuat apabila ada pesanan), kedua jual langsung ke pasar, dan terakhir di borong atau di beli oleh pengebul dari Lombok. Menurut data tabel diatas bahwa dari 31 kelompok hanya 3 kelompok yang menggunakan 
media digital atau $10,3 \%$ dari total kelompok.

Strategi pemasaran diperlukan dalam suatu perusahan dengan maksud agar semua rencana yang telah ditentukan dapat dijalankan secara maksimal. Strategi pemasaran tidak terlepas dari peran komunikasi dalam menjembatani rangkaian cara untuk mencapai tujuan yang diinginkan. Tjiptono, (1997: 29) dalam Dewi \& Nugraha (2015) mengatakan bahwa komunikasi pemasaran adalah aktivitas pemasaran yang tujuannya untuk menyebarkan informasi, mempengaruhi, membujuk dan mengingatkan pasar sasaran atas perusahaan dan produknya agar bersedia menerima, membeli dan loyal kepada produk yang ditawarkan.

Pada komunikasi pemasaran yang kental akan periklanan Tom Duchan dalam Morisson (2010), menilai proses komunikasi membutuhkan bauran media dan perencanaan media terdiri dari empat langkah, yaitu: 1) Mengidentifikasi Target Media (Media Targeting); 2) Menentukan tujuan Media (Media Objectives); 3) Menentukan strategi media; 4) Penjadwalan Penempatan media (Scheduling media placement). Maka strategi komunikasi pemasaran menurut Tom Duchan pada Kelompok pandai besi Desa Leseng adalah:

\section{Mengidentifikasi Target Media}

Menentukan target media, adalah mengindetifikasi sasaran konsumen yang dituju, seperti sifat dan karakteristik dari manusia pada umumnya. Sehingga langkah selanjutnya yaitu tugas perencanaan media nantinya akan memilih media dan menentukan pasar dengan konsumen yang memiliki sifat atau karakteristik paling sesuai dengan konsumen sasaran. Dari ketiga informan yang mewakili kelompoknya, memiliki jawaban yang berbeda-beda dalam mengidentifikasi target konsumen dalam menggunakan media digital.

Identifikasi target konsumen dalam menggunakan media, bahwasannya dalam menetukan target masing-masing informan berbeda-beda, dan target yang telah dipenuhi hanya sebagian kecil dari target sasaran. Lebih banyak masih ruang lingkup lokal Sumbawa. Dua informan sama-sama baru mencapai satu daerah diluar pulau Sumbawa, sedangkan Informan ketiga yaitu pak ES mampu menyebarkan hingga kelima daerah diluar pulau Sumbawa. Sayangnya apabila dikaitkan dengan pentingnya menentukan karakteristik target konsumen, ketiga informan tidak mengindentifikasi konsumen secara spesifik atau detail. Gagasan pada langkah awal tidak dapat diambil. Apakah banyaknya target yang tidak terpenuhi dipengaruhi oleh tidak spesifiknya target konsumen yang dituju, atau ada faktor lainnya sehingga menyebabkan kegagalan dari pencapaian target.

\section{Menentukan Tujuan Media}

Menentukan tujuan media dalam hal ini adalah memilih penggunaan media dan menjelaskan bagaimana pemasar menyampaikan pesannya kepada konsumen sedemikian rupa sehingga pesan didalam media yang digunakan memberikan efek terhadap pikiran, perasaan, dan tindakan konsumen. Adapun ketiganya menggunakan media yang sama, yaitu Facebook dan WhatsApp, mengunakan akun pribadi bukan akun resmi kelompok. Dan mereka merancang pesan yang akan diposting memiliki 
beberapa pola yang sama, yaitu pertama gambar parang dan sedikit keterangan.

Langkah kedua ini perencanaan masih sangat mendasar dari perencaan pesan. Karena dalam merencanakan pesan seharusnya memaksimalkan daya tarik untuk menarik konsumen agar membeli produk yang ditawarkan dengan perencanaan pesan yang bagus. Misalkan, memaksimalkan design produk maupun pengambilan gambar yang estektik. Rancangan pesan yang efektif adalah target konsumen berada pada pasar sasaran yang diinginkan, mendapat sifat-sifat pesan yang disampaikan atau efek seperti apa yang diharapkan oleh penjual terjadi terhadap diri konsumen. Termasuk menciptakan kesadaran atau pengetahuan mengenai produk dengan berbagai atributnya, menginformasikan kelebihan produk, menciptakan citra produk, atau menciptakan sikap yang positif, preferensi dan keinginan membeli produk bersangkutan.

\section{Menentukan Strategi Media}

Pada tahap ketiga yaitu strategi media adalah bagaimana rancangan pesan dapat dimaksimalkan dalam media yang gunakan. Pada hal ini perajin parang menggunakan Facebook dan WhatsApp sebagai medium penyampai pesan. Ketiga informan menggunakan Facebook dan WhatsApp tetapi didalam media tersebut terdapat grup-grup yang menjadi target konsumen, sebagai strateginya masingmasing.

Dari masing-masing penggunaan media, meskipun menggunakan media yang sama, namun dengan cara pengunaan yang berbeda maka hasilnya akan berbeda. Informan yang paling banyak menggunakan media adalah informan (pak
ES), meski menggunakan aplikasi yang sama yaitu facebook dan WhatsApp tetapi jika cara mengelolaannya berbeda, dalam facebook menandai 80 grup dan frekuensi penyebaran semakin luas maka penerima pesannya didapat juga semakin banyak.

Seperti karakteristik media massa yang disampaikan oleh McQuail (1999) dalam Ahmad (2007), yang mendistribusikan informasi dalam skala besar, sehingga proses komunikasi diterima oleh masyarakat dalam sekali siaran diterima oleh ruang lingkup yang sangat luas. Pemasaran juga membutuhkan audiens luas untuk mendapatkan efek dari pesan, membuka peluang untuk mempersuasi calon konsumen sehingga memiliki keputusan membeli.

\section{Penjadwalan Penempatan Media}

Penjadwalan media, Tujuan utama dari penjadwalan adalah mengatur waktu berbagai kegiatan promosi yang bertepatan dengan potensi waktu pembelian tertinggi. Perencanaan media harus memilih kapan waktu yang paling tepat agar pesan dapat diterima oleh sebanyak mungkin target konsumen.

Ketiga informan sama-sama menaikan harga di media, daripada penjualan langsung. Dimana jika beli borongan diberikan potongan perbarang. Dan untuk waktu ramai informan (pak P) pada awal bulan, waktu gajian turun. Informan (pak E) dan (pak ES) waktu ramainya pembeli menjelang musim tani dibulan Desember dan bulan Januari, sebelum waktu orang ramai memakainya.

Kesimpulan pada tahapan keempat, meskipun pada musim ramai, tidak ada kelompok perajin parang yang memberikan promo secara khusus. Padahal pada sebuah pemasaran produk, 
waktu promo adalah salah satu yang ditunggu oleh konsumen, terlebih masyarakat Indonesia.

Dari empat tahapan dalam startegi komunikasi pemasaran Tom Duchan melalui media yang dilakukan oleh perajin parang, ketiga informan, sebenarnya masih belum memahami apa yang sebenarnya mereka lakukan dalam pemasaran di media sosial. Seperti ketika mendeksripsikan target konsumen, mereka lebih mengeneralisir target, tetapi pada kenyataan ditahapan selanjutnya pada tahap ketiga mereka membuat strategi menyebarkannya kedalam grup-grup yang ada di Facebook, termasuk komunitaskomunitas terkait dengan produk maupun daerah yang dituju. Karakteristik dari grup dan komunitas terkait yang terpilih merupakan bagian target dari target konsumen yang mereka inginkan, tetapi mereka kurang menyadari hal itu. Pada kesimpulannya perajin parang tidak mengidentifikasi target konsumen dengan baik.

\section{KESIMPULAN}

Berdasarkan hasil penelitian dan pembahasan tentang strategi penggunaan media digital yang dilakukan oleh perajin parang Desa Leseng, adalah terdapat 31 kelompok perajin parang, dan yang menggunakan media digital hanya 3 kelompok perajin parang. Perajin Parang dalam startegi penggunaan media digitalnya menggunakan media WhatsApp dan Facebook, dan pada penyebaran pesannya perajin parang menyebarkan pesan ke grup atau halaman yang ada di Facebook dan WhatsApp. Semakin banyak grup atau jangkauan penyebaran pesan semakin luas maka semakin banyak penerima informasi (konsumen) yang membeli parang.
Sayangnya penyebaran tersebut masih belum maksimal hal ini dilihat dari akun yang digunakan masih menggunakan akun pribadi oleh masing-masing perajin parang. Strategi penggunaan media oleh perajin parang apabila dianalisis menggunakan teori juga belum menerapkan konsep tersebut dengan baik. Dalam teori ada 4 tahapan, pertama target media, atau bisa dikatakan target konsumen, perajin parang tidak menetukan target konsumen secara spesifik, dan dalam ruang lingkup pemasaran masih banyak pada lokal Sumbawa. Kedua tujuan media, yaitu media yang digunakan, dan rancangan pesan dalam media digital, perajin parang dalam perancangan media menggunakan media facebook dan whatsapp tetapi menggunakan akun pribadi masingmasing, dan pola merancang pesan yang sama, yaitu gambar, keterangan barang, dan harga tanpa informasi lebih tentang keunggulan konsumen harus membeli produk tersebut. Ketiga strategi, strategi yang mereka lakukan hanya menyebarkan pesan ke grup/halaman yang ada di Facebook dan WhatsApp. Keempat penjadwalan media, menentukan waktu terbaik dalam promosi, perajin parang tidak memiliki waktu terbaik untuk melakukan promosi, tetapi mengalami musim ramai pembeli adalah pada musim tani yaitu Desember dan Januari.

\section{DAFTAR PUSTAKA}

Creswell, Jhon. (2016). Research Design: Pendekatan metode kualitatif, kuantitatif, dan campuran edisi empat. Yogyakarta: Pustaka Pelajar.

Elvina, Devina dan Tioris, Farencia. (2018). Kreasi Produk Kreatif Hadapi Revolusi Industri 4.0 Teknik 
Makrame Eceng Gondok ke Media Ban Sepeda Motor. Seminar Nasional Seni dan Desain: "Konvergensi Keilmuan Seni Rupa dan Desain Era 4.0”. Jurnal FBS Unesa.

Gumilar, Gumgum. (2015). Pemanfaatan Instagram Sebagai Sarana Promosi oleh Pengelola Industri Kreatif Fashion di Kota Bandung. Jurnal Ilmu Politik dan Komunikasi. Vol. V No. 2. 77-84.

Kurniawati, Dewi dan Arifin, Nugraha. (2015). Strategi Pemasaran Melalui Media Sosial dan Minat Beli Mahasiswa. Jurnal Simbolika Vol 1 No.2. 193-198.

Mulyana, Ahmad. 2007. Modul Sosiologi Komunikasi. Universitas Mercu Buana: Jogja.

Morrisan. (2010). Periklanan: Komunikasi Pemasaran Terpadu. Jakarta: Kencana.

Muttaqin, Zainal. dan Ali, Mohammad. (2011) Perancangan Pusat
Komunikasi Bisnis UMKM Berbasis Sistem Terintegrasi.

Prasetyo, Hoedi dan Wahyudi, Wahyudi. (2018). Industri 4.0: Telaah Klasifikasi Aspek Dan Arah Perkembangan Riset. Jurnal Teknik Industri, Vol. 13 No.1. 17-26. 